\title{
Antifungal and antioxidant activities of mature leaves of Myrcia splendens (Sw.) DC.
}

\author{
F. C. Pontes ${ }^{a}$, V. C. P. Abdalla ${ }^{a}$, M. Imatomi ${ }^{a}$, L. F. G. Fuentes ${ }^{a}$ and S. C. J. Gualtieri ${ }^{a}$ \\ aPrograma de Pós-graduação em Ecologia e Recursos Naturais, Laboratório de Ecofisiologia de Sementes, Universidade \\ Federal de São Carlos - UFSCar, Rodovia Washington Luís, Km 235, CP 676, CEP 13565-905, São Carlos, SP, Brasil \\ *e-mail: vivicpereira@gmail.com
}

Received: May 11, 2017 - Accepted: August 14, 2017 - Distributed: February 28, 2019

\begin{abstract}
In recent years, natural products with antifungal and antioxidant activities are being increasingly researched for a more sustainable alternative to the chemicals currently used for the same purpose. The plant pathogenic fungus Alternaria alternata is a causative agent of diseases in citrus, leading to huge economic losses. Antioxidants are important for the production of medicines for various diseases that may be related to the presence of free radicals, such as cancer, and in the cosmetic industry as an anti-aging agent and the food industry as preservatives. This study evaluated the antifungal and antioxidant potential of extracts of mature leaves of Myrcia splendens, a tree species that occurs in the Brazilian Cerrado. The antioxidant potential was analyzed by an assay of 1,1-diphenyl-2-picrylhydrazyl radical-scavenging method, and the antifungal activity was assessed through the evaluation of mycelial growth. Majority of the extracts exhibited a strong antioxidant activity, especially the acetonic extract (4A). The antioxidant activity may be related to the presence of phenolic compounds. However, the extracts showed no inhibitory activity of mycelial growth of the fungus tested, with the exception of dichloromethanic extract (2B), which had an inhibitory effect $(10.2 \%)$ at the end of testing.
\end{abstract}

Keywords: Myrtaceae, biological activity, Alternaria alternata, Alternaria brown spot.

\section{Atividade antifúngica e antioxidante de folhas maduras de Myrcia splendens (Sw.)DC.}

\begin{abstract}
Resumo
A busca de produtos naturais com atividades antifúngica e antioxidante tem crescido nos últimos anos como alternativa mais sustentável para os produtos químicos atualmente usados para estas funções. O fungo fitopatogênico Alternaria alternata é agente causador de doenças nos citros, levando a grandes perdas econômicas. Substâncias antioxidantes são importantes tanto para a produção de medicamentos para diversas doenças que podem estar relacionadas à presença de radicais livres, como o câncer, bem como para a indústria cosmética, como agentes anti-envelhecimento e para a indústria alimentícia, como conservantes. Este trabalho avaliou o potencial antifúngico dos extratos de folhas maduras de Myrcia splendens, uma espécie arbórea que ocorre no cerrado brasileiro. O potencial antioxidante foi analisado por meio de ensaio da capacidade sequestrante do radical 1,1-diphenyl-2-picrylhydrazyl e o antifúngico, por meio da avaliação do crescimento micelial. A maioria dos extratos apresentou atividade antioxidante muito forte, especialmente o extrato acetônico (4A). A atividade antioxidante pode ser relacionada a presença de compostos fenólicos. Por outro lado, os extratos não apresentaram atividade inibitória do crescimento micelial do fungo testado, com exceção do extrato diclorometânico (2B), que foi o único que teve efeito inibitório $(10,2 \%)$ ao final do teste.
\end{abstract}

Palavras-chave: Myrtaceae, atividade biológica, Alternaria alternata, mancha marrom da Alternaria.

\section{Introduction}

Secondary metabolites have been used by human beings since ancient times in their isolated form as extracts or even as fresh or dried plants such as tinctures, flavorings, fragrances, stimulants, hallucinogens, insecticides, poisons, and therapeutic agents (Wink, 2010). In plants, most of these metabolites play important roles in plant protection against pathogens (viruses, bacteria, and fungi), competing plants, and herbivores. They may also have physiological functions such as protection against ultraviolet radiation and as nitrogen storage compounds (Jansen et al., 2008; Wink, 2010).

Some compounds from plant secondary metabolism may also exhibit antioxidant activity. Reactive oxygen species (ROS) are often generated as by-products of 
regular cell metabolism, but they can also be induced by environmental stimuli such as exposure to high levels of light, drought, heavy metals, high salt concentrations, temperature extremes, ultraviolet radiation, air pollution, use of herbicides, and attack of pathogens and herbivores (Gill and Tuteja, 2010). Antioxidants delay auto-oxidation by inhibiting the formation of free radicals or by stopping the spread of free radicals (Brewer and Prestat, 2002). Currently, the interest in natural antioxidants, especially those of vegetal origin, has increased, since the presence of free radicals and oxidative stress may be associated with the development of diseases such as cancer, diabetes, atherosclerosis, inflammatory processes, and aging (Sikora et al., 2008). In addition, oxidative stress is also a problem for the food industry, modifying the smell, taste, and nutritional value of food (Krings and Berger, 2001).

The fungus Alternaria alternata is the causal agent of three citrus diseases, namely, Alternaria brown spot, Alternaria leaf spot, and black rot (Kimati et al., 2005; Woudenberg et al., 2015). These diseases cause significant commercial losses, and the pathogen is controlled by the use of fungicides such as Mancozeb, Difenconazole, Propiconazole, Myclobutani, Carbendazim, Thiophanate methyl, Copper oxychloride, Copper hydroxide, and Benomyl (Thejakumar and Devappa, 2016). Several currently used fungicides are toxic to both humans and other organisms, including those that may be beneficial to agricultural crops (Newton et al., 2010). According to Wink (2010), as most of the substances from plant secondary metabolism have insecticidal, fungicidal, and phytotoxic activities, they can act as natural pesticides and be less harmful to the environment. In addition, natural products can serve as a model for the development of synthetic drugs (Demain, 2009). In this context, the search for antifungal compounds in plants may be interesting (Khan and Nasreen, 2010).

Among the 250,000-500,000 plant species estimated to exist, only a small percentage of them have been investigated for phytochemistry and an even smaller fraction of these species have been subjected to biological and pharmacological tests (Mahesh and Satish, 2008). Myrcia splendens (Sw.) DC. is a species belonging to the family Myrtaceae found in the Brazilian Cerrado and is popularly known as "guamirim" and "folha-miúda". It is a tree species occurring from Mexico to the south of Brazil (Oliveira-Filho and Fontes, 2000; Morais and Lombardi, 2006). According to Oliveira-Filho (2006), some synonyms of this species are Myrcia acutata DC., Myrcia rostrata DC., Myrcia communis Berg., and Myrcia fallax (Rich.) DC.

In this context, this study aimed to evaluate the antioxidant and antifungal potential of extracts of mature leaves of $M$. splendens, from two types of extraction, against the phytopathogen $A$. alternata.

\section{Material and Methods}

\subsection{Collection and preparation of plant material}

Mature leaves of Myrcia splendens (Sw.) DC. (Myrtaceae) were collected in the Cerrado sensu stricto (Neotropical savanna) reserve belonging to the campus of the Universidade Federal de São Carlos, São Carlos-SP $\left(21^{\circ} 58^{\prime}-22^{\circ} 00^{\prime} \mathrm{S}\right.$ and $\left.47^{\circ} 51^{\prime}-47^{\circ} 52^{\prime} \mathrm{W}\right)$, in the dry season. The region is characterized by dry winter (April to September) and rainy summer (October-March). Leaves with dark green coloration and coriaceous texture were considered as mature. A voucher specimen (8317) has been deposited at the Herbarium at Universidade Federal de São Carlos (HUFSCar).

The collected leaves were dried in an oven at $40^{\circ} \mathrm{C}$ for $72 \mathrm{~h}$. Afterward, they were crushed in an electric mill to obtain the powder from the leaves, which was packed in a plastic bag and stored under refrigeration (approximately $5^{\circ} \mathrm{C}$ ) until used.

\subsection{Extract preparation}

Two extraction procedures were performed. The former procedure used solvents in increasing order of polarity (eluotropic): hexane (Hx), dichloromethane (DCM), ethyl acetate (AcoEt), acetone (AC), and methanol $(\mathrm{MeOH})$. Ground dried leaves of $M$. splendens $(50 \mathrm{~g})$ were added to $300 \mathrm{~mL}$ of $\mathrm{Hx}$. This mixture was ultrasonicated for $15 \mathrm{~min}$ followed by filtration. This process was performed three times with each solvent using the same residual ground dried leaves from the filtrations with each further extraction. The filtrates of each solvent were dried, resulting in the extracts $1 \mathrm{~A}$ (hexane), $2 \mathrm{~A}$ (dichloromethane), 3A (ethyl acetate), 4A (acetonic), and 5A (methanolic). The hexane extract $1 \mathrm{~A}$ was used only to remove waxes and lipids from ground dried leaves and then discarded.

In the second extraction method, $50 \mathrm{~g}$ of ground dried leaves of $M$. splendens was extracted with $300 \mathrm{~mL}$ of $\mathrm{DCM} / \mathrm{MeOH}(1: 1)$ in an ultrasonic bath for $30 \mathrm{~min}$. Then, the mixture was filtered to obtain the crude extract. This process was repeated five times until the filtrate reached a lighter color, indicating that the plant material was being depleted. The obtained crude extract was dried and then diluted in $300 \mathrm{~mL}$ of $\mathrm{MeOH} /$ distilled water (95:5) and partitioned with $300 \mathrm{~mL}$ of distilled water to give the hexane (1B) and methanolic-aqueous extracts. Finally, the methanolic-aqueous extract was dried and diluted in $300 \mathrm{~mL}$ of distilled water and partitioned with $300 \mathrm{~mL}$ of AcoEt, giving the extracts ethyl acetate (2B) and aqueous (3B) (Otsuka, 2005).

\subsection{Bioautography in thin-layer chromatography (TLC)}

Bioautography determines the presence of compounds in the extracts with antioxidant activity. The tests were performed according to Luo et al. (2009). The extracts were solubilized in organic solvents $\left(1 \mathrm{mg} \cdot \mathrm{mL}^{-1}\right)$, according to the polarity of extracts, and deposited directly on TLC plates. These plates were eluted in a mixture of organic solvents suitable for the polarity of the extracts analyzed and sprayed with methanolic solution of 1,1-diphenyl-2-picrylhydrazyl (DPPH) at $0.4 \mathrm{mg} \cdot \mathrm{mL}^{-1}$. Extracts containing compounds with antioxidant activity were observed as white bands on a purple background.

\subsection{Antioxidant activity assay}

Compounds with antioxidant activity in the extracts evaluated were determined by the DPPH method (Scherer and Godoy, 2009, with modifications). The extracts 
were solubilized in methanol at different concentrations (0.1-16.0 mg. $\left.\mathrm{mL}^{-1}\right)$. Aliquots of $0.05 \mathrm{~mL}$ of each extract were added to tubes containing $1.95 \mathrm{~mL}$ of DPPH methanolic solution $(0.08 \mathrm{mM})$. Two controls were prepared, one negative, containing methanol PA, and the other positive, containing quercetin, a commercial antioxidant. The final concentration of DPPH in each tube, after addition of controls or extracts, was $30.75 \mu \mathrm{L} \cdot \mathrm{mL}^{-1}$. The tubes were kept for $90 \mathrm{~min}$ in the dark at room temperature $\left(25^{\circ} \mathrm{C}\right)$. The absorbance was measured at $517 \mathrm{~nm}$. The assay was performed in triplicate.

The antioxidant activity was calculated according to the percentage of inhibition equation as follows: $\mathrm{I} \%=\left[\left(\mathrm{Abs}_{0}-\mathrm{Abs}_{1}\right) / \mathrm{Abs}_{0}\right] \times 100$, where $\mathrm{Abs}_{0}$ is the absorbance of the negative control, and $\mathrm{Abs}_{1}$ is the absorbance of the treatment. Each extract was tested at five concentrations. $\mathrm{The} \mathrm{IC}_{50}$ (concentration at which there is $50 \%$ inhibition) was calculated graphically by the linear regression of the antioxidant activity of the extracts at the five concentrations evaluated. The antioxidant activity of each of the extracts was expressed using the antioxidant activity index (AAI) (Scherer and Godoy, 2009) as follows: $\mathrm{AAI}=$ final concentration of DPPH $\left(\mu 1 . \mathrm{mL}^{-1}\right) / \mathrm{IC}_{50}\left(\mu \mathrm{g} \cdot \mathrm{mL}^{-1}\right)$.

Then, the extracts were classified according to their AAI into weak (AAI $<0.5$ ), moderate (AAI between 0.5 and 1.0 ), strong (AAI between 1.0 and 2.0), and very strong (AAI > 2.0).

\subsection{Bioassay of antifungal activity}

The antifungal potential of the extracts was verified by the evaluation of mycelial growth of the phytopathogenic fungus Alternaria alternata (LRS 182/10) isolated from Ponkan tangerine and obtained from the mycology collection of "Dr. Victoria Rossetti" (UPDS/APTA/SAA), Sorocaba, Sao Paulo.

Fungi were previously reactivated on potato dextrose agar (PDA) medium in Petri dishes and kept in incubator (B.O.D) at $25{ }^{\circ} \mathrm{C}$ with a photoperiod of $12-12 \mathrm{~h}$ for approximately 20 days (until covering three-fourths of the Petri dishes).

The extracts were dissolved in $1 \%$ DMSO, filtered in a $0.22-\mu \mathrm{m}$ filter, and incorporated into the PDA culture medium at about $40^{\circ} \mathrm{C}$ at the concentration of $1 \mathrm{mg} \cdot \mathrm{mL}^{-1}$. The negative control was prepared using PDA medium and DMSO. Four replicates of each treatment were made in $5 \mathrm{~cm}$ plastic Petri dishes. The fungus was inoculated with mycelial disks of approximately $5 \mathrm{~mm}$ in diameter at the center of each plate, which were kept in the incubator at $25^{\circ} \mathrm{C}$ and a photoperiod of $12-12 \mathrm{~h}$

The diameter of the mycelial growth was measured using a digital caliper on two orthogonal axes (mean of two diametrically opposite measures). Measurements were made every $48 \mathrm{~h}$, totaling 10 measurements (19 days). On each measurement day, the percentage of inhibition of growth (IG) by the treatments in relation to the control was calculated using the following Formula 1:

$I G(\%)=\left(\frac{\text { Diameter of the treatment }- \text { diameter of the control }}{\text { diameter of the control }}\right) \times 100(1)$

\subsection{Statistical analyses}

The linear regression graphs of the antioxidant activity were plotted using the Microsoft ${ }^{\circledR}$ Excel program. The $\mathrm{IC}_{50}$ values in the antioxidant assay and the mean diameters of the mycelium of the fungus were submitted to a normality test (Shapiro-Wilk test). The statistical difference was calculated at a significance of $5 \%$ using the Welch's test for normal data or the Wilcoxon test for nonnormal data. These analyses were performed in the R software (R Development Core Team, 2014).

\section{Results and Discussion}

Bioautography on the TLC plates showed that all the evaluated extracts had antioxidant compounds, which was evidenced by the white bands revealed with DPPH solution.

Therefore, the antioxidant activity assays were performed with all extracts (Table 1).

The antioxidant activity can be of two types, for example, primary when the compounds bind to free radicals and secondary if the compounds have chelating capacity of transition metals and synergism can occur when both modes are present (Fennema, 2000). The DPPH-sequestering ability assay assesses the ability of antioxidants to eliminate free radicals and is indicated for the screening of samples with different polarities (Scio et al., 2012). This test is based on the discoloration of a solution composed of the stable free radical DPPH of violet color, when the addition of substances that can yield a hydrogen atom (Brand, et al., 1995). Antioxidants capable of reducing the DPPH radical are characterized as primary (Yen and Chen, 1995).

Extracts $2 \mathrm{~B}, 3 \mathrm{~B}, 5 \mathrm{~A}$, and $4 \mathrm{~A}$ exhibited very strong antioxidant activity (AAI). The $3 \mathrm{~A}$ showed strong AAI, 1B had moderate AAI, and 2A showed weak AAI according to the classification established by Scherer and Godoy (2009). The highest AAI values were obtained by more polar extracts. Extract 4A (acetonic extract from eluotropic extraction) was distinguished by its antioxidant activity, representing $>50 \%$ of the quercetin activity, a pure antioxidant. Furthermore, $4 \mathrm{~A}$ presented $\mathrm{IC}_{50}$ value lower than $3.6 \mu \mathrm{g} \cdot \mathrm{mL}^{-1}$ which is close to the value obtained for quercetin. The solvent extraction methodology in the eluotropic order was more efficient in obtaining extracts with higher antioxidant activity (acetonic extract (4A) and dichlorometanic extract (5A)).

Plants with antioxidant and pharmacological properties are usually related to the presence of phenolic compounds, especially phenolic acids and flavonoids (Gulçin, 2012). The antioxidant capacity of these compounds is primarily attributed to their oxide-reducing properties, allowing them to act as reducing agents, hydrogen donors, and singlet oxygen suppressors (Gülçin et al., 2010). The primary techniques used for the isolation of phenolic compounds are solvent extraction, supercritical fluid extraction, and ultrasonic-assisted extraction (Ignat et al., 2011). The use of acidified methanol, ethanol, acetone, ethyl acetate, and mixtures of these solvents with water has been reported in the literature (Annegowda et al., 2012; Haminiuk et al., 
2011; Prasad et al., 2011; Pushp et al., 2013; Ramful et al., 2011; Wijekoon et al., 2011; Sasidharan and Menon, 2011). In this study, the extracts with stronger antioxidant activities were extracted using solvents such as acetone (4A) and methanol (5A), and hence this activity may also be associated with the presence of polyphenolic compounds or other substances with hydroxyl groups available to donate a hydrogen atom to the molecule oxidant (Mensor, 1999).

These results are consistent with other studies that demonstrated the antioxidant potential of $M$. splendens leaves. The methanolic extract of leaves of this species exhibited a high antioxidant potential that was associated with the presence of polyphenolic compounds in the extract (Scio et al., 2012). Similarly, butanolic fractions and ethyl acetate extracts of $M$. splendens showed a high reduction potential and DPPH radical elimination, as well as high concentrations of phenolic compounds and flavonoids (Moresco et al., 2014).

In the bioassay of antifungal activity, the extract 2B significantly inhibited the mycelial growth in relation to the control, reaching $10.2 \%$ inhibition on the last day of the bioassay (Table 2). Treatments made with extracts 5A and 4A stimulated mycelial growth. Thus, the liquid-liquid partition extraction method was more efficient to obtain extracts with antifungal activity.
The antifungal activity of Myrtaceae species has been reported in the literature, especially with regard to its essential oils (Miles et al., 1991; Cerqueira et al., 2007; Zabka et al., 2014). However, there are few studies on the antifungal potential of Myrcia splendens. Moresco (2014) found that several extracts of $M$. splendens showed high inhibition against Candida strains, especially C. krusei and $C$. tropicalis. On the other hand, methanolic extracts of leaves of $M$. splendens did not exhibit any inhibitory activity in Candida albicans and Cryptococcus neoformans (Scio et al., 2012). In a research on the antifungal activity of aqueous and hydroethanolic extracts of Cerrado species, Naruzawa and Papa (2011) observed that extracts of Aristolochia esperanzae and Byrsonima verbascifolia stimulated the growth of the phytopathogenic fungus Corynespora cassiicola, while extracts of Lafoensia pacari and Myracrodruon urundeuva inhibited $100 \%$ of the mycelial growth of the same fungus.

Due to its wide range of hosts and distribution in the world, the fungus Alternaria sp. has been reported to be responsible for causing diseases in 400 plant species (Chung, 2012). The diseases caused by this fungus are among the most common plant diseases in the world and are characterized by affected seedlings, leaves, stems, Flowers, and fruits of vegetables belonging to Solanaceae,

Table 1. Antioxidant activity of extracts of mature leaves of Myrcia splendens.

\begin{tabular}{ccccccc}
\hline \multirow{2}{*}{ Extracts } & \multicolumn{2}{c}{$\mathbf{R}^{\mathbf{2}}$} & & \multirow{2}{*}{$\mathbf{I C}_{\mathbf{5 0}}\left(\boldsymbol{\mu} \mathbf{g} \cdot \mathbf{m L}^{-\mathbf{1}}\right)$} & \multirow{2}{*}{$\mathbf{I A A} \pm \mathbf{S D}$} & \multirow{2}{*}{ Antioxidant power } \\
\cline { 2 - 4 } & $\mathbf{I}$ & $\mathbf{I I}$ & $\mathbf{I I}$ & & & \\
\hline 2A & 0.99331 & 0.9928 & 0.95745 & 324.59 & $0.096 \pm 0.012^{\mathrm{a}}$ & Weak \\
1B & 0.96923 & 0.99628 & 0.9841 & 52.34 & $0.595 \pm 0.079^{\mathrm{b}}$ & Moderate \\
3A & 0.98744 & 0.97639 & 0.99147 & 16.01 & $1.923 \pm 0.067^{\mathrm{c}}$ & Strong \\
2B & 0.99724 & 0.99074 & 0.98413 & 8.03 & $3.924 \pm 0.782^{\mathrm{de}}$ & Very Strong \\
3B & 0.99837 & 0.99692 & 0.9924 & 7.56 & $4.069 \pm 0.047^{\mathrm{d}}$ & Very Strong \\
5A & 0.99771 & 0.98424 & 0.96258 & 6.49 & $4.737 \pm 0.074^{\mathrm{e}}$ & Very Strong \\
4A & 0.97075 & 0.97392 & 0.97346 & 3.60 & $8.537 \pm 0.201^{\mathrm{f}}$ & Very Strong \\
Quercetin & 0.98782 & 0.94894 & 0.9723 & 2.055 & $14.97 \pm 0.22^{\mathrm{g}}$ & Very Strong \\
\hline
\end{tabular}

$\mathrm{R}^{2}$ : coefficient of determination between the antioxidant activity and the concentration of the extract/quercetin solution in each repetition (I, II, and III); $\mathrm{IC}_{50}$ : concentration displaying 50\% inhibition; SD: standard deviation; AAI: Antioxidant activity index. Means followed by equal letters in the column did not differ from each other $(\mathrm{P}<0.05)$. Antioxidant potential was determined according to Scherer and Godoy (2009).

Table 2. Percentage of inhibition or stimulation of the mycelial growth of the fungus Alternaria alternata treated with the extracts of mature leaves of Myrcia splendens on each day of measurement. Negative values indicate inhibition and positive values indicate stimulation.

\begin{tabular}{|c|c|c|c|c|c|c|c|c|c|c|}
\hline & $\begin{array}{l}\text { Day } 1 \\
(24 \text { h) } \\
\end{array}$ & $\begin{array}{l}\text { Day } 3 \\
(72 \text { h) } \\
\end{array}$ & $\begin{array}{c}\text { Day } 5 \\
(120 \text { h })\end{array}$ & $\begin{array}{c}\text { Day } 7 \\
(168 \text { h })\end{array}$ & $\begin{array}{c}\text { Day } 9 \\
(216 \text { h }) \\
\end{array}$ & $\begin{array}{l}\text { Day } 11 \\
(264 \mathrm{~h})\end{array}$ & $\frac{\text { Day } 13}{(312 \text { h })}$ & $\begin{array}{l}\text { Day } 15 \\
(360 \text { h }) \\
\end{array}$ & $\begin{array}{l}\text { Day } 17 \\
(408 \text { h }) \\
\end{array}$ & $\begin{array}{l}\text { Day } 19 \\
(456 \text { h) } \\
\end{array}$ \\
\hline $2 \mathrm{~A}$ & $-1.8 \%$ & $6.6 \%$ & $12.0 \%$ & $6.9 \%$ & $5.9 \%$ & $5.2 \%$ & $2.3 \%$ & $6.7 \%$ & $8.1 \%$ & $5.7 \%$ \\
\hline $3 \mathrm{~A}$ & $-0.8 \%$ & $15.2 \% *$ & $23.4 \% *$ & $20.3 \%$ & $18.1 \%$ & $11.2 \%$ & $4.9 \%$ & $10.4 \%$ & $9.1 \%$ & $3.1 \%$ \\
\hline $4 \mathrm{~A}$ & $6.3 \%$ & $28.2 \% *$ & $37.9 \% *$ & $37.1 \% *$ & $31.0 \% *$ & $27.2 \% *$ & $22.8 \% *$ & $21.2 \% *$ & $17.4 \% *$ & $10.8 \% *$ \\
\hline $5 \mathrm{~A}$ & $17.8 \% *$ & $20.4 \% *$ & $27.1 \% *$ & $24.2 \% *$ & $21.0 \% *$ & $21.2 \% *$ & $17.9 \% *$ & $13.7 \% *$ & $11.8 \%$ & $6.7 \%$ \\
\hline 1B & $14.2 \% *$ & $10.4 \% *$ & $14.2 \%$ & $11.8 \%$ & $15.3 \%$ & $16.3 \%$ & $12.5 \%$ & $14.1 \%$ & $12.7 \%$ & $7.4 \%$ \\
\hline $2 \mathrm{~B}$ & $7.3 \%$ & $1.0 \%$ & $-0.3 \%$ & $-5.3 \%$ & $-7.4 \%$ & $-6.3 \%$ & $-9.6 \% *$ & $-8.6 \% *$ & $-8.7 \% *$ & $-10.2 \% *$ \\
\hline $3 \mathrm{~B}$ & $18.8 \% *$ & $13.4 \%$ & $23.3 \%$ & $17.0 \%$ & $16.0 \%$ & $14.1 \%$ & $7.8 \%$ & $8.5 \%$ & $7.7 \%$ & $3.5 \%$ \\
\hline
\end{tabular}

*In the same column indicates treatments with a significant difference in relation to the negative control on each day. 
Apiaceae, Alliaceae, Cruciferaceae, and Cucurbitaceae families (Töfoli et al., 2015). The Alternaria brown spot (ABS) is a disease caused by Alternaria alternata that primarily affects the leaves and fruits of tangerine and its hybrids, which results in great losses in production, besides being a disease of difficult control (Carvalho et al., 2011). In one of the few studies evaluating the activity of natural products against the plant pathogen $A$. alternata, it was found that the essential oil of Piper hispidinervum showed fungitoxic activity on the mycelial growth of this fungus (La Torre et al., 2014; Llorens et al., 2017). Although the inhibitory activity presented by extract $2 \mathrm{~B}$ in the present study is considered low, it refers to extracts and not to isolated compounds; therefore, subsequent studies with this extract are encouraged.

\section{Conclusions}

Four extracts showed very strong antioxidant activity, especially the acetonic extract (4A). On the other hand, only the dichloromethane extract (2B) had an inhibitory effect $(10.2 \%)$ on the mycelial growth of Alternaria alternata. Therefore, mature leaves of Myrcia splendens are an important source of antioxidant compounds and may commercially be applied in the future. Despite exhibiting a low effect, studies with this extract are encouraged to search for substances that may be responsible for the inhibitory effect of the extract and that when isolated may have more intense activities.

\section{References}

ANNEGOWDA, H., BHAT, R., MIN-TZE, L., KARIM, A. and MANSOR, S., 2012. Influence of sonication treatments and extraction solvents on the phenolics and antioxidants in star fruits. Journal of Food Science and Technology, vol. 49, no. 4, pp. 510-514. http://dx.doi.org/10.1007/s13197-011-0435-8. PMid:23904662.

BRAND, W., CUVELIER, M.E. and BERSET, C., 1995. Use of a free radical method to evaluate antioxidant activity. Food Science and Technology, vol. 28, no. 1, pp. 25-30.

BREWER, M.S. and PRESTAT, C., 2002. Consumer attitudes towards issues in food safety. Journal of Food Safety, vol. 22, no. 2, pp. 67-85. http://dx.doi.org/10.1111/j.1745-4565.2002.tb00331.x.

CARvalho, D.D.C., Alves, E., CAMARgos, R.B., OLIVEIRA, D.F., SCOLFORO, J.R.S., CARVALHO, D.A. and BATISTA, T.R.S., 2011. Plant extracts to control Alternaria alternata in Murcott tangor fruits. Revista Iberoamericana de Micologia, vol. 28, no. 4, pp. 173-178. http://dx.doi.org/10.1016/j. riam.2011.05.001. PMid:21635961.

CERQUEIRA, M.D., SOUZA-NETA, L.C., PASSOS, M.G.V.M., LIMA, E.O., ROQUE, N.F., MARTINS, D., GUEDES, M.L.S. and CRUZ, F.G., 2007. Seasonal variation and antimicrobial activity of Myrcia myrtifolia essential oils. Journal of the Brazilian Chemical Society, vol. 18, no. 5, pp. 998-1003. http://dx.doi. org/10.1590/S0103-50532007000500018.

CHUNG, K.R., 2012. Stress response and pathogenicity of the necrotrophic fungal pathogen Alternaria alternata. Scientifica, vol. 2012, pp. 1-17. http://dx.doi.org/10.6064/2012/635431. PMid:24278721.

DEMAIN, A.L., 2009. Antibiotics: natural products essential to human health. Medicinal Research Reviews, vol. 29, no. 6, pp. 821-842. http://dx.doi.org/10.1002/med.20154. PMid:19291695.

FENNEMA, O.R., 2000. Química de los alimentos. 2nd ed. Zaragoza: Acribia. 1258 p.

GILL, S.S. and TUTEJA, N., 2010. Reactive oxygen species and antioxidant machinery in abiotic stress tolerance in crop plants. Plant Physiology and Biochemistry, vol. 48, no. 12, pp. 909-930. http://dx.doi.org/10.1016/j.plaphy.2010.08.016. PMid:20870416.

GÜLÇIN, İ., 2012. Antioxidant activity of food constituents: an overview. Archives of Toxicology, vol. 86, no. 3, pp. 345-391. http://dx.doi.org/10.1007/s00204-011-0774-2. PMid:22102161.

GÜLÇIN, I., HUYUT, Z., ELMASTAS, M. and ABOULENEIN, H.Y., 2010. Radical scavenging and antioxidant activity of tannic acid. Arabian Journal of Chemistry, vol. 3, no. 1, pp. 43-53. http://dx.doi.org/10.1016/j.arabjc.2009.12.008.

HAMINIUK, C., PLATA-OVIEDO, M.S.V., GUEDES, A.R., STAFUSSA, A.P., BONA, E. and CARPES, S.T., 2011. Chemical, antioxidant and antibacterial study of Brazilian fruits. Journal of Food Science and Technology, vol. 46, no. 7, pp. 1529-1537. http://dx.doi.org/10.1111/j.1365-2621.2011.02653.x.

IGNAT, I., VOLF, I. and POPA, V.I., 2011. A critical review of methods 195 for characterisation of polyphenolic compounds in fruits and vegetables. Food Chemistry, vol. 126, no. 4, pp. 1821-1835. http://dx.doi.org/10.1016/j.foodchem.2010.12.026. PMid:25213963.

JANSEN, M.A.K., HECTORS, K., O'BRIEN, N.M., GUISEZ, Y. and POTTERS, G., 2008. Plant stress and human health: do human consumers benefit from UV-B acclimated crops? Plant Science, vol. 175, no. 4, pp. 448-458. http://dx.doi.org/10.1016/j. plantsci.2008.04.010.

KHAN, Z.S. and NASREEN, S., 2010. Phytochemical analysis, antifungal activity and mode of action of methanol extracts from plants against pathogens. Agricultural Technology, vol. 6, no. 4, pp. 793-805

KIMATI, H., AMORIM, L., BERGAMIN FILHO, A., CAMARGO, L.E.A. and REZENDE, J.A.M., 2005. Manual de fitopatologia: doenças das plantas. 4th ed. São Paulo: CERES. 706 p. vol. 2.

KRINGS, U. and BERGER, R.G., 2001. Antioxidant activity of some roasted foods. Journal Food Chemistry, vol. 72, no. 2, pp. 223-229. http://dx.doi.org/10.1016/S0308-8146(00)00226-0.

LA TORRE, A., CARADONIA, F., GIANFERRO, M., MOLINU, M.G. and BATTAGLIA, V., 2014. Activity of natural products against some phytopathogenic fungi. Communications in Agricultural and Applied Biological Sciences, vol. 79, no. 3, pp. 439-449. PMid:26080478.

LLORENS, E., GARCÍA-AGUSTÍN, P. and LAPENA, L., 2017. Advances in induced resistance by natural compounds: towards new options for woody crop protection. Scientia Agrícola, vol. 74, no. 1, pp. 90-100. http://dx.doi.org/10.1590/1678-992x-2016-0012.

LUO, H., YAMAMOTO, Y., A KIM, J., JUNG, J.S., KOH, Y.J. and HUR, J.-S., 2009. Lecanoric acid, a secondary lichen substance with antioxidant properties from Umbilicaria antarcticain maritime Antarctica (King George Island). Polar Biology, vol. 32, no. 4, pp. 1033-1040. http://dx.doi.org/10.1007/s00300-009-0602-9. 
MAHESH, B. and SATISH, S., 2008. Antimicrobial activity of some important medicinal plants against plant and human pathogens. World Journal of Agricultural Sciences, vol. 4, no. 5, pp. 839-843.

MENSOR, L.L., 1999. Avaliação da atividade antioxidante em plantas brasileiras. Rio de Janeiro: Universidade Federal do Rio de Janeiro. Dissertação de Mestrado.

MILES, D.H., MEDEIROS, J.M.R., CHITTAWONG, V., HEDIN, P.A., SWITHENBANK, C. and LIDERT, Z., 1991. 3'-formyl-2', 4',6'-trihydroxydihydrochalcone from Psidium acutangulum. Phytochemistry, vol. 30, no. 4, pp. 1131-1132. http://dx.doi.org/10.1016/S0031-9422(00)95188-4.

MORAIS, P.O. and LOMBARDI, J.A., 2006. A Família Myrtaceae na Reserva Particular do Patrimônio Natural da Serra do Caraça, Catas Altas, Minas Gerais, Brasil. Lundiana, vol. 7, no. 1, pp. 3-32.

MORESCO, H.H., 2014. Estudo fitoquímico e biológico de quatro espécies da família Myrtaceae. Florianópolis: Programa de Pós-graduação em Química, Centro de Ciências Físicas e Matemáticas, Universidade Federal de Santa Caratina, 190 f. Tese de Doutorado em Química.

MORESCO, H.H., PEREIRA, M., BRETANHA, L.C., MICKE, G.A., PIZZOLATTI, M.G. and BRIGHENTE, I.M.C., 2014. Myricitrin as the main constituent of two species of Myrcia. Journal of Applied Pharmaceutical Science, vol. 4, no. 2, pp. 1-7.

NARUZAWA, E.S. and PAPA, M.F.S., 2011. Antifungal activity of extracts from Brazilian Cerrado plants on Colletotrichum gloeosporioides and Corynespora cassiicola. Revista Brasileira de Plantas Medicinais, vol. 13, no. 4, pp. 408-412. http://dx.doi. org/10.1590/S1516-05722011000400006.

NEWTON, A.C., FITT, B.D., ATKINS, S.D., WALTERS, D.R. and DANIELL, T.J., 2010. Pathogenesis, parasitism and mutualism in the trophic space of microbe plant interactions. Trends in Microbiology, vol. 18, no. 8, pp. 365-373. http://dx.doi. org/10.1016/j.tim.2010.06.002. PMid:20598545.

OLIVEIRA-FILHO, A.T. and FONTES, M.A.L., 2000. Patterns of floristic differentiation among Atlantic Forests in southeastern Brazil and the influence of climate. Biotropica, vol. 32, no. 4, pp. 793-810. http://dx.doi.org/10.1646/0006-3606(2000)032[0793:PO FDAA]2.0.CO;2.

OLIVEIRA-FILHO, A.T., 2006. Catálogo das árvores nativas de Minas Gerais: mapeamento e inventário da flora nativa e dos reflorestamentos de Minas Gerais. Lavras: UFLA. 423 p.

OTSUKA, H., 2005. Purification by solvent extraction using partition coefficient. In: S.D. SARKER, Z. LATIF and A.I. GRAY, eds. Natural products isolation. methods in biotechnology. 2nd ed. Totowa: Human Press. vol. 20, pp. 269-273.

PRASAD, K.N., HASSAN, F.A., YANG, B., KONG, K.W., RAMANAN, R.N., AZLAN, A. and ISMAIL, A., 2011. Response surface optimisation for the extraction of phenolic compounds and antioxidant capacities of underutilised Mangifera pajang Kosterm. peels. Food Chemistry, vol. 128, no. 4, pp. 1121-1127. http://dx.doi.org/10.1016/j.foodchem.2011.03.105.

PUSHP, P., SHARMA, N., JOSEPH, G.S. and SINGH, R.P., 2013. Antioxidant activity and detection of $(-)$ epicatechin in the methanolic extract of stem of in the methanolic extract of stem of Tinospora cordifolia. Journal of Food Science and Technology, vol. 50, no. 3, pp. 567-572. http://dx.doi.org/10.1007/s13197011-0354-8. PMid:24425954.

R DEVELOPMENT CORE TEAM, 2014 [viewed 1 March 2015]. $R$ : a language and environment for statistical computing [software]. Vienna: R Foundation for Statistical Computing. Available from: http://www.R-project.org

RAMFUL, D., AUMJAUD, B., NEERGHEEN, V.S., SOOBRATTEE, M.A., GOOGOOLYE, K., ARUOMA, O.I. and BAHORUN, T., 2011. Polyphenolic content and antioxidant activity of Eugenia pollicina leaf extract in vitro and in model emulsion systems. Food Research International, vol. 44, no. 5, pp. 1190-1196. http://dx.doi.org/10.1016/j.foodres.2010.09.024.

SASIDHARAN, I. and MENON, A., 2011. Effects of temperature and solvent on antioxidant properties of curry leaf (Murraya koenigii L.). Journal of Food Science and Technology, vol. 48, no. 3, pp. 366-370. http://dx.doi.org/10.1007/s13197-010-0134-x. PMid:23572760.

SCHERER, R. and GODOY, H.T., 2009. Antioxidant activity index (AAI) by the 2.2-diphenyl-1-picrylhydrazyl method. Food Chemistry, vol. 112, no. 2, pp. 654-658. http://dx.doi.org/10.1016/j. foodchem.2008.06.026

SCIO, E., MENDES, R.F., MOTTA, E.V.S., BELLOZI, P.M.Q., ARAGÃO, D.M.O., MELLO, J., FABRI, R.L., MOREIRA, J.R., ASSIS, I.V.L. and BOUZADA, M.L.M., 2012 [viewed 1 March 2015]. Antimicrobial and antioxidant activities of some plant extracts. In: V. RAO, ed. Phytochemicals as nutraceuticals: global approaches to their role in nutrition and health [online]. Croatia: InTech. Available from: http://www.intechopen.com/ books/phytochemicals-as-nutraceuticals-global-approaches-totheir-role-in-nutrition-and-health/antimicrobial-and-antioxidantactivities-of-some-plant-extracts. http://dx.doi.org/10.5772/27308.

SIKORA, E., CIESLIK, E. and TOPOLSKA, K., 2008. The sources of natural antioxidants. Acta Scientiarum Polonorum. Technologia Alimentaria, vol. 7, no. 1, pp. 5-17.

THEJAKUMAR, M.B. and DEVAPPA, V., 2016. Efficacy of different fungicides against Alternaria alternata and Cercospora capsici under in vitro conditions. International Journal of Advanced Research in Biological Sciences, vol. 3, no. 5, pp. 126-129.

TÖFOLI, J.G., DOMINGUES, R.J. and FERRARI, J.T., 2015. Alternaria spp. em Oleráceas: sintomas, etiologia, manejo e fungicidas. O Biológico, vol. 77, no. 1, pp. 21-34.

WIJEKOON, M., BHAT, R. and KARIM, A.A., 2011. Effect of extraction solvents on the phenolic compounds and antioxidant activities of bunga kantan (Etlingera elatior Jack.). Food Chemistry, vol. 117 , no. 4 , pp. $252-277$.

WINK, M., 2010. Biochemistry, physiology and ecological functions of secondary metabolites. In: M. WINK, ed. Annual plant reviews: biochemistry of plant secondary metabolism. 2nd ed. Oxford: Wiley-Blackwell, vol. 40, pp. 1-19. http://dx.doi. org/10.1002/9781444320503.ch1.

WOUDENBERG, J.H., SEIDL, M.F., GROENEWALD, J.Z., VRIES, M., STIELOW, J.B., THOMMA, B.P. and CROUS, P.W., 2015. Alternaria section Alternaria: species, formae speciales or pathotypes? Studies in Mycology, vol. 82, pp. 1-21. http://dx.doi. org/10.1016/j.simyco.2015.07.001. PMid:26951037.

YEN, G.C. and CHEN, H.Y., 1995. Antioxidant activity of various tea extracts in relation to their antimutagenicity. Journal of Agricultural and Food Chemistry, vol. 43, no. 1, pp. 27-32. http://dx.doi.org/10.1021/jf00049a007.

ZABKA, M., PAVELA, R. and PROKINOVA, E., 2014. Antifungal activity and chemical composition of twenty essential oils against significant indoor and outdoor toxigenic and aeroallergenic fungi. Chemosphere, vol. 112, pp. 443-448. http://dx.doi.org/10.1016/j. chemosphere.2014.05.014. PMid:25048938. 